milk, mortar, nickel, photography, analysis (qualitative and quantitative), nitric acid, nitrates, salts, oxygen, gunpowder, sulphur, sulphuric acid, silver, specific gravity, thermometer, porcelain, hyposulphites, water, wine, tartrates, tungstates, sugar, \&c. The following subjects are treated of in some detail:-Alcoholometry, aniline dyes, areometer, iron, carbonates, light, mineral waters, common salt, sulphates, heat.

The value of the dictionary as a work of reference is decidedly enhanced by the adoption of thick type for the words heading the articles. In the case of recently discovered compounds we are of opinion that a short bibliographical reference to the paper wherein such compounds are first made known would have greatly increased the value of the articles without materially adding to their length. The author has fallen into an error in treating of thermo- and pyro-electricity under the same heading; the former term is employed by electricians in this country to denote the electricity developed by heat in conductors, the latter to denote the electricity produced by heat in mon-conductors.

Bearing in mind the enormous range of subjects now embraced by the science of chemistry, for a volume of the present size the amount of information conveyed is really very great. With the exception above pointed out, the articles, though necessarily brief, are to be depended on for accuracy, and we can safely recommend Dr. Dammer's dictionary as a useful work of reference.

$$
\text { R. M. }
$$

Clouds in the East. Travels and Adventures on the Perso-Turkoman Frontier. By Valentine Baker. With Maps and Illustrations. (London: Chatto and Windus, I 876.$)$

THE author of this interesting volume had special facilities for visiting the Russian outposts in Asia and the Persian frontier; he had powerful recommendations to the highest Russian and Persian authorities. By various causes, however, he was prevented from taking complete advantage of these, so that the main part of his work describes his joumeys in the district to the south of the Caspian, and from Teheran towards the north-east Persian frontier. He reached the Caspian by Trebizond and Tiflis, and gives some interesting particulars as to navigation on the inland sea. He was able to visit the mouth of the much-talked-of Attrek, and found that the Gurgan, to the south of the Attrek, is the real Russian frontier in this region. He was unfortunately prevented from visiting Merv and Herat, which he had intended to do. Mr. Baker's main objects were sport and to ascertain the real nature of the advances made by Russia in Central Asia. Of the former he got a fair amount around Teheran, and his work will be of very considerable importance to those who are interested in the movements of Russia. He took considerable pains to ascertain Persian feeling on the question ; Persia cannot understand, or rather misunderstands, England's inaction. Mr. Baker gives many valuable notes as to the nature of the country passed over, its productions, antiquities, and inhabitants. Concerning the Turkomans especially, and their wonderful houses, many details will be found. Altogether the work is an intelligent and interesting narrative of travel in an important region, and a substantial contribution to the Asian question. There are three good maps, but the chromolithographs are very poor specimens of their kind.

\section{LETTERS TO THE EDTTOR}

The Editor does not hold himself responsible for opinions expressed by his correspondents. Neither can he undertake to return, or to correspond with the woriters of, rejected manuscripts. No notice is taken of anonymous communications.]

The Use of the Words "Weight" and "Mass"

'I wILL supplement Mr. Bottomley's authorities for the meaning of gravity by others which will he perhaps considered more relevant. Maupertuis, "Figure de la Terre," Paris, I 738 , writes:- "Il faut bien distinguer ici la pesanteur d'un corps d'avec son poids . . L La pesanteur dans un grand corps, n'est pas plus grande que dans un petit. Il n'en est pas ainsi dn poids ; il dépend non-seulement de la pesanteur, mais encore de la masse des corps . . . il est le produit de la pesanteur par la masse" (p. 155). Subsequently, he lays down the distinction between pesanteur and gravité which Clairaut adopted; but universally the English gravity has been used as synonymous with the French pesanteur. Airy, "Gravitation," p. 3: "To take the ordinary force of gravity for an instance, we might measure it by the pressure which is produced on the hand ... or by the number of inches through which the lump of lead would fall in a second of time... But there is this difference between the two measures ; if we adopted the first ... we should find a different measure by the use of every different piece of lead; whereas if we adopt the second... wre shall get the same measure for gravity whatever body we suppose subject to its influence." Here the broad distinction between "weight" and "gravity" is clearly laid down; the one is the "impressed force" on the falling body, the other its "accelerative effect" (Thomson and Tait, "Treatise on Nat. Phil.," 2 I 7-2I9), or the more familiar " moving force" and "accelerating force." In the "Treatise" the former is called the "force of gravity on the mass of a body," 220; but "gravity" alone seems clearly enough defined as acceleration, by the words "According to this formula, therefore, polar gravity will be

Again, $\$ 226$ : "The augmentation of gravity per degree . . is, at most . . The average . . . differs certainly but little from $32 \cdot 2 . "$

I think it evident that gravity has not been "lying ready for use, but left almost i 3 le," as Mr. Bottomiey supposes.

To the restriction on the use of weight-which I feebly support, but which is certainly not mine--I do not conceive that the "Act of Parliament" offers any bar; as the weights of masses are merely thereby defined in terms of the weight of the standard mass. This restricted sense is clearly recognised in such passages as the following, from Thomson and Tait's "Elements," $\$ 366$, "The measurement of force whether in terms of the weight of a stated mass in a stated locality ..."

As to the compounds "centivires," \&c., I advisedly adopted the Latin prefixes in their old etymological sense, so as to have wholly Latin names and thereby prevent any confusion with the C. G. S. kitetic measures. The employment in the metric system being quite conventional and contrary to analogy, I feel justified in following older precedents.

\section{J. J. WALKER}

\section{"The Recent Origin of Man"}

IN NATURE, vol. xiii. p. 245 , a writer over the initials "W. B. D." reviews in no very complimentary terms my book entitled "The Recent Origin of Man." I am charged with inconsistency, inaccuracy, incompetency, \&c. When charges of this sort are made they ought not to be made lightly, and the writer making them ought to wcigh his statements.

My space is necessarily brief, but I beg permission to comment on a few of the assertions made by "W. B. D." in renderiing his judgment on the premises.

I. He remarks: "The statement that no traces of a rude and imperfect civilisation have been met with in the East is refuted by the discovery of enormous quantiries of flint implements in Egypt and of neolithic axes in Asia Minor and in India. In the river gravels of both these regions paleolithic hutches have been found of the same type as those of Amiens and Abbeville."

We all know that palrolithic implements have been found in the river-gravels of India; I refer to this on p. $3 \mathrm{I}$ of $\mathrm{my}$ book but I am not aware that palæolithic implements have been found in the river-gravels of Egypt or Asia Minor. As "W. B. D." asserts it, I beg leave to ask for the particulars.

As for the occurrence of flint implements in Egypt, I remark on p. 478: "Flint implements have been found in Egypt but they belong to the Neolithic age, and occur on the surface, or near the surface, or in the tombs." I mention that one implement of palæolithic type had been found. I show that flint arrow heads and flint knives have been frequently found in the Egyptian tombs by the side of the mummies.

That Sir Jolm Lubbock found in the Nile valley a few implements resembling the palæolithic types I am aware; but implements of palæolithic type were found at Cissbury by Col. A. 